\title{
A descriptive study of prevalence of musculoskeletal illnesses among farmers in faisalabad, Pakistan
}

Received: 18 January, 2021

Accepted: 25 January, 2021

Published: 27 January, 2021

*Corresponding author: Umair Arif, Lecturer School of Management and Sciences, University of Faisalabad, Pakistan, Tel: 03226037531; E-mail: umair.arif@tuf.edu. pk, umairrana1765@gmail.com

Keywords: Farmers; Musculoskeletal disorders; Nordic; REBA

https://www.peertechz.com

\section{Check for updates}

\section{Osama Saeed ${ }^{1}$, Umair Arif ${ }^{2 *}$, Muhammad Usman Saqib ${ }^{3}$, Abubakar Sidiqque $^{4}$, Hammas Khalid ${ }^{5}$ and Aneeq Shahzad ${ }^{6}$ \\ 'Demonstrator, School of Rehabilitation Sciences, University of Faisalabad, Pakistan \\ ${ }^{2}$ Lecturer School of Management and Sciences, University of Faisalabad, Pakistan \\ ${ }^{3}$ Doctor of Physiotherapy School of Rehabilitation Sciences, University of Faisalabad, Pakistan \\ ${ }^{4}$ Doctor of Physiotherapy School of Rehabilitation Sciences, University of Faisalabad, Pakistan \\ ${ }^{5}$ Student Doctor of Physiotherapy School of Rehabilitation Sciences, University of Faisalabad, Pakistan \\ ${ }^{6}$ Student Doctor of Physiotherapy School of Rehabilitation Sciences, University of Faisalabad, Pakistan}

\section{Abstract}

Background/objectives: The farming employs about half the world's entire workforce. In most countries, farming is recognized as one of the most hazardous industries. Farming activities lead to awkward physical postures. These postures are: leaning, kneeling, crawling, bending, twisting to one side and repeated work that can result in physical stress and traumatic injuries. This study aimed to evaluate the ergonomic conditions and musculoskeletal symptoms among farmers in Faisalabad, Pakistan.

Methods/statistical analysis: This descriptive study was conducted on 80 farmers from different regions of Faisalabad who were between 25 to 80 years old and harvesting traditionally. Nordic Questionnaire (NMQ) was used for determining prevalence rate of musculoskeletal disorders.

Results: The obtained results indicated that the most reported musculoskeletal disorders in farmers are neck, wrist, low back with $75 \%, 77.5 \%, 66.25 \%$ respectively. We checked prevalence of MDS in different phases of harvesting, in 1st phase low back, neck, wrist with $88.75 \%, 87.5 \%, 82.5 \%$ respectively have the most musculoskeletal problems in farmers during sedentary picking up with hand. In 2nd phase low back, ankle, knee with 90\%, 85\%, 73.75\% respectively have the most musculoskeletal problems in farmers during standing picking up with sickle. In 3rd phase knee, low back, hip with 93.75\%, 90\%, 73.75\% respectively have the most musculoskeletal problems in farmers during collecting harvests from farm. In 4th phase hip, low back, ankle with $96.62,92.5 \%, 77.5 \%$ respectively have the most musculoskeletal problems in farmers during packing.

Conclusion: Low back pain is the major problem among farmers caused by harvesting harvests from farming, according to the results. Results indicate that harvesting plays a major role in the prevalence of musloskeletal disorders in the various parts of the body of the farmer. In the prevalence of muscloskeletal disorders of farmers, the height and age of farmers have a major role. The research showed that the working conditions of the studies farmers are unsustainable and need to be changed. As most farming practices are historically carried out priority based solution steps to minimize musculoskeletal disorders can be classified as training of ergonomics concepts in farming activities regular inspection and replacement of technical farming methods.

\section{Introduction}

Musculoskeletal Disorders (MSDs) are basically a number of disorders that are the results of abnormal posture and prolonged sitting and standing [1-3]. Workers about half of workforce of the world is affected by the musculoskeletal disorders by farming orders. Farming is considers as the one of the most hilarious industry which affects the most of the muscles, 
tendons, ligame3nts and blood vessels. Rather than any other occupational activities, there is a huge risk of work related musculoskeletal disorders in farming [4-6]. This is basically due to the nature of activity of farming that farmers are the one that is most affected by the this $[7,8]$. There are so many abnormal activities and motions are present in farming such as kneeling, leaning, crawling, twisting to one side, crawling, lifting and carrying weight and repeated motions that leads towards the mechanical strain and abnormal stress to the body and causes trauma $[9,10]$. There are about 3 main risk factors in the activities of farmers that causes the MSDs in farmers that are lifting and carrying different weights, repetition occurs in whole body such as bending and highly repetition of work by hands $[11,12]$. According to one study, there are the following disorders that are cussed in farmers are shoulders disorders [13], hip joint osteoarthritis [14], low back pain [15], disorders related to hand and wrist such as carpel tunnel syndrome [16], forearm disorders [17], knee osteoarthritis, disorders of upper limb, trauma like fractures, sprain and dislocations 9. Prevalence of MSDs in farmers are about more than $50 \%$ than other people [18]. There are about $60 \%$ of work related MSDs are reported during previous 12 months in Kansas farmers of southeast10. The study on Netherlands farmers by Hartman and et al showed that the MSDs are the basic and important reason of sick leave by self-employed farmers $[19,20]$. The main purpose of this study which is done in Eastern Azerbaijan's and Iran's farmers is to assess the prevalence of MSDs related to farming and harvesting activities and to know the risk factors of MSDs in this population.

\section{Materials and methods}

The descriptive study was conducted with farmers in parts of Pakistan. Total 80 farmers were included in the study who worked customarily. Nordic Musculoskeletal Questionnaire (NMQ) was used for data collection. Prevalence rate of musculoskeletal disorders through determining NMQ. It was 6 month study from July-01-2020 to December-22-2020 by last year students. 1st we discussed demographic features of farmers. The rest part of questionnaire is about musculoskeletal symptom in different parts of body. It was completed after accessing musculoskeletal disorders form formers. Totally harvest activities were divided into 4 phases: sedentary picking up with hand, standing picking up with sickle, collecting harvests from farm and packing phase. A statistical analysis was performed with SPSS for Windows (version 23).

\section{Results}

In this study 80 farmers were analyzed that their mean height was $5^{\prime} .7^{\prime \prime} \pm 3^{\prime} .75^{\prime \prime}$ inches, body weight was $80.25 \pm$ $5.14 \mathrm{~kg}$, mean age was $29.85 \pm 3.25$, BMI was $22.71 \pm 2.75$. 6th month earlier response about musculoskeletal symptoms were recorded in Table 1 . This table shows that neck, wrist, low back with $75 \%, 77.5 \%, 66.25 \%$ respectively have the most musculoskeletal problems in farmers. After that ankle, knee, hip with $90 \%, 83.75 \%, 77.5 \%$ respectively have the most musculoskeletal problems in farmers during 1 month earlier response about it (Table 2). We checked prevalence of MDS in different phases of harvesting, in 1st phase low back, neck, wrist with $88.75 \%, 87.5 \%, 82.5 \%$ respectively have the most musculoskeletal problems in farmers during sedentary picking up with hand (Table 3). In 2nd phase low back, ankle, knee with $90 \%, 85 \%, 73.75 \%$ respectively have the most musculoskeletal problems in farmers during standing picking up with sickle (Table 4). In 3rd phase knee, low back, hip with $93.75 \%$, 90\%, $73.75 \%$ respectively have the most musculoskeletal problems in farmers during collecting harvests from farm (Table 5). In 4th phase hip, low back, ankle with 96.62, 92.5\%, 77.5\% respectively have the most musculoskeletal problems in farmers during packing (Table 6). Overall phase's results are shown in Figure 1.

Table 1: Response of musculoskeletal symptoms during 6 months earlier to being interviewed.

\begin{tabular}{|c|c|c|c|}
\hline & \multicolumn{2}{|c|}{ Response } & Total \\
\hline Parts of body & Yes & No & \\
\hline Ankle & $7(8.75 \%)$ & $73(91.25 \%)$ & 80 \\
\hline Knee & $23(28.75 \%)$ & $57(71.25 \%)$ & 80 \\
\hline Hip & $30(37.5 \%)$ & $50(62.5 \%)$ & 80 \\
\hline Low back & $53(66.25 \%)$ & $27(33.75 \%)$ & 80 \\
\hline Wrist & $62(77.5 \%)$ & $18(22.5 \%)$ & 80 \\
\hline Neck & $60(75 \%)$ & $20(25 \%)$ & 80 \\
\hline
\end{tabular}

Table 2: Response of musculoskeletal symptoms during 1 months earlier to being interviewed

\begin{tabular}{|c|c|c|c|}
\hline & \multicolumn{2}{|c|}{ Response } & Total \\
\hline Parts of body & Yes & No & \\
\hline Ankle & $72(90 \%)$ & $08(10 \%)$ & 80 \\
\hline Knee & $67(83.75 \%)$ & $13(16.25 \%)$ & 80 \\
\hline Hip & $62(77.5 \%)$ & $18(22.5 \%)$ & 80 \\
\hline Low back & $50(62.5 \%)$ & $30(37.5 \%)$ & 80 \\
\hline Wrist & $45(56.25 \%)$ & $35(43.75 \%)$ & 80 \\
\hline Neck & $40(50 \%)$ & $40(50 \%)$ & 80 \\
\hline
\end{tabular}

Table 3: Prevalence of MSDs in $1^{\text {st }}$ phase of harvesting( sedentary picking up with hand).

\begin{tabular}{|c|c|c|c|}
\hline & \multicolumn{2}{|c|}{ Response } & Total \\
\hline Parts of body & Yes & No & \\
\hline Ankle & $61(76.25 \%)$ & $19(23.75 \%)$ & 80 \\
\hline Knee & $63(78.75 \%)$ & $17(21.25 \%)$ & 80 \\
\hline Hip & $57(71.25 \%)$ & $23(28.75 \%)$ & 80 \\
\hline Low back & $71(88.75 \%)$ & $09(11.25 \%)$ & 80 \\
\hline Wrist & $66(82.5 \%)$ & $14(17.5 \%)$ & 80 \\
\hline
\end{tabular}

Table 4: Prevalence of MSDs in $2^{\text {nd }}$ phase of harvesting (standing picking up with sickle).

\begin{tabular}{|c|c|c|c|}
\hline & \multicolumn{2}{|c|}{ Response } & Total \\
\hline Parts of body & Yes & No & \\
\hline Ankle & $68(\%)$ & $12(15 \%)$ & 80 \\
\hline Knee & $59(\%)$ & $21(26.25 \%)$ & 80 \\
\hline Hip & $50(\%)$ & $20(25 \%)$ & 80 \\
\hline Low back & $72(\%)$ & $08(10 \%)$ & 80 \\
\hline Wrist & $57(\%)$ & $23(28.75 \%)$ & 80 \\
\hline Neck & $54(\%)$ & $26(32.5 \%)$ & 80 \\
\hline
\end{tabular}

Citation: Saeed O, Arif U, Saqib MU, Sidiqque A, Khalid H, et al. (2021) A descriptive study of prevalence of musculoskeletal illnesses among farmers in faisalabad, Pakistan. J Nov Physiother Phys Rehabil 8(1): 001-004. DOI: https://dx.doi.org/10.17352/2455-5487.000084 
Table 5: Prevalence of MSDs in $3^{\text {rd }}$ phase of harvesting (collecting harvests from farm)

\begin{tabular}{|c|c|c|c|}
\hline & \multicolumn{2}{|c|}{ Response } & Total \\
\hline Parts of body & Yes & No & \\
\hline Ankle & $51(63.75 \%)$ & $29(36.25 \%)$ & 80 \\
\hline Knee & $75(93.75 \%)$ & $05(6.25 \%)$ & 80 \\
\hline Hip & $59(73.75 \%)$ & $22(27.5 \%)$ & 80 \\
\hline Low back & $72(90 \%)$ & $08(10 \%)$ & 80 \\
\hline Wrist & $56(70 \%)$ & $24(30 \%)$ & 80 \\
\hline Neck & $58(72.5 \%)$ & $22(27.5 \%)$ & 80 \\
\hline
\end{tabular}

Table 6: Prevalence of MSDs in $4^{\text {th }}$ phase of harvesting (packing).

\begin{tabular}{|c|c|c|c|}
\hline & \multicolumn{2}{|c|}{ Response } & Total \\
\hline Parts of body & Yes & No & \\
\hline Ankle & $62(77.5 \%)$ & $18(22.5 \%)$ & 80 \\
\hline Knee & $52(65 \%)$ & $28(35 \%)$ & 80 \\
\hline Hip & $77(96.25 \%)$ & $03(3.75 \%)$ & 80 \\
\hline Low back & $74(92.5 \%)$ & $06(7.5 \%)$ & 80 \\
\hline Wrist & $51(63.75 \%)$ & $29(36.25 \%)$ & 80 \\
\hline Neck & $70(87.5 \%)$ & $10(12.5 \%)$ & 80 \\
\hline
\end{tabular}

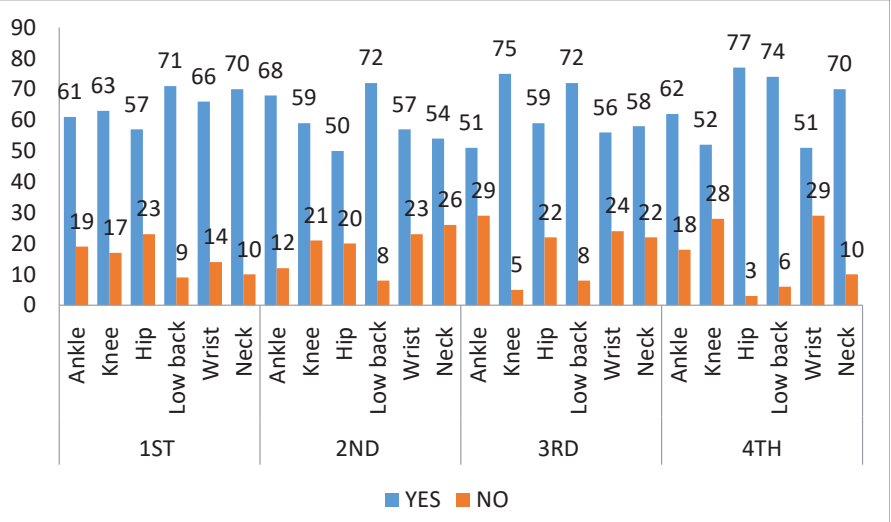

Figure 1: All phases overall outcomes.

\section{Discussion}

Through results, it is cleared that about more than $75 \%$ of farmers are associated with the pain at neck pain. $66.25 \%$ of farmer which do harvesting suffer from back pain. According to the situations, it is confirmed that the low back pain of farmers are occurred due to abnormal postures such as way of doing wirst, way of doing bend and the repeated motion are the major risk of MSDs. As a result of repeated hand and wrist motions, there are about $77.5 \%$ with wrist pain and $75 \%$ of neck pain associated farmers suffering from MSDs. After checking their musculoskeletal problems there should be rehabilitation treatments and some knowledge about after hard work and continues musculoskeletal problems. In a cohart study done by Kirkhorn, et al. it is reported that the prevalence of osteoarthritis which is occurred due to repeated motions is more in farmers than non-farmers persons. Study on MSDs in Irish farmers by Osborne, it Is stated that the back pain is the most common experienced MSDs in farmers while shoulder disorders is the second one [18]. Many other studies also indicated the prevalence of shoulder disorders in farmers. In the study on Kansas farmers done by Rosecrance and et al, about $60 \%$ of farmers reported the MSDs in the preceding 12 months [10]. These parameters are also shown by many other studies [22]. Harvest season is the most busiest duration regarding work for farmer while remaining period are quite relaxing for farmer and they are busy in others activities. Due to this, the non-farming activities can also cause the prevalence of MSDs in farmers. The comparison between pain occur in body parts of last week and the pain of body parts in the last year is done to determent the role of harvest season in the prevalence of MSDs in farmers. It is found that the rate of disorders of last week is increased significantly than the rate of disorders of last 12 months [21]. The relation present between the low back pain stature and the knee pain-stature shows the effect of stature in the prevalence of MSDs in famers. Another background factor that causes the prevalence of MSDs in farmer is age, which is shown by the relationship of age with pain occur in low back, elbow, shoulder and knee. The Osborne study indicated that the farmer's age is not a major factor of prevalence of MSDs in Farmers [22]. In the view of REBA assessment and prioritization, all the stages and phases of farming is dangerous and have potential to lead towards the musculoskeletal disorders. All the postures are urgently be corrected by the ergonomics interventions in sedentary picking of object by hands. The posture of farmers as well as in other stages of farming should be corrected [23].

\section{Conclusion}

Low back pain is the major problem among farmers caused by harvesting harvests from farming, according to the results. Results indicate that harvesting plays a major role in the prevalence of musloskeletal disorders in the various parts of the body of the farmer. In the prevalence of muscloskeletal disorders of farmers, the height and age of farmers have a major role. The research showed that the working conditions of the studies farmers are unsustainable and need to be changed. As most farming practices are historically carried out priority based solution steps to minimize musculoskeletal disorders can be classified as training of ergonomics concepts in farming activities regular inspection and replacement of technical farming methods. After checking their musculoskeletal problems there should be rehabilitation treatments and some knowledge about exercises for them after hard work and in continues musculoskeletal problems. It will resolve their problem and helps them for their working.

\section{References}

1. Susanto T, Purwandari R, Wuryaningsih EW (2017) Prevalence and associated factors of health problems among Indonesian farmers. Chinese Nursing Research 4: 31-37. Link: https://bit.ly/3c5wQw8

2. Udom C, Janwantanakul P, Kanlayanaphotporn R (2016) The prevalence of low back pain and its associated factors in Thai rubber farmers. $J$ Occup Health 58: 534-542. Link: https://bit.ly/3paFNbb

3. Takahashi A, Kitamura K, Watanabe Y, Kobayashi R, Saito T, et al. (2018) Epidemiological profiles of chronic low back and knee pain in middle-aged and elderly Japanese from the Murakami cohort. J Pain Res 11: 3161-3169. Link: https://bit.ly/369D7TK 
4. Kiadaliri AA, Gerhardsson de Verdier M, Turkiewicz A, Lohmander LS, Englund M (2017) Socioeconomic inequalities in knee pain, knee osteoarthritis, and health-related quality of life: a population-based cohort study in southern Sweden. Scand J Rheumatol 46: 143-151. Link: https://bit.ly/3oh8W30

5. Vanwonterghem K (1996) Work-related musculoskeletal problems: Some ergonomic considerations. J Hum Ergol 25: 5-13. Link: https://bit.ly/39ercWE

6. Rostamabadi A, Jahangiri M, Naderi Mansourabadi B, Javid M, Ghorbani M, et al. (2019) Prevalence of chronic diseases and occupational injuries and their influence on the health-related quality of life among farmers working in smallfarm enterprises. J Agromedicin 24: 248-256. Link: https://bit.ly/3odW4L9

7. Kolstrup CL, Jakob M (2016) Epidemiology of musculoskeletal symptoms among milkers and dairy farm characteristics in Sweden and Germany. J Agromedicine 21: 43-55. Link: https://bit.ly/2YcnxSY

8. Nash CGR, Kelton DF, DeVries TJ, Vasseur E, Coe J, et al. (2016) Prevalence of and risk factors for hock and knee injuries on dairy cows in tiestall housing in Canada. J Dairy Sci 99: 6494-6506. Link: https://bit.ly/39ZbVs2

9. Kang MY, Lee MJ, Chung H, Shin DH, Youn KW, et al. (2016) Musculoskeletal disorders and agricultural risk factors among Korean farmers. J Agromedicine 21: 353-363. Link: https://bit.ly/39besA1

10. Bernard BP (1997) Musculoskeletal Disorders and Workplace Factors. Cincinnati, Centers for Disease Control and Prevention (CDC). National Institute for Occupational Safety and Health (NIOSH). Link: https://bit.ly/2YexVcE

11. Min D, Baek S, Park HW, Lee SA, Moon J, et al. (2016) Prevalence and characteristics of musculoskeletal pain in Korean farmers. Ann Rehabil Med 40: 1. Link: https://bit.ly/2NAGMDF

12. Min D, Baek S, Park HW, Lee SA, Moon J, et al. (2016) Prevalence and characteristics of musculoskeletal pain in Korean farmers. Ann Rehabil Med 40: 1-13. Link: https://bit.ly/3qN1E91

13. Zeng C, Wei J, Terkeltaub R, Yang T, Choi HK, et al. (2017) Dose-response relationship between lower serum magnesium level and higher prevalence of knee chondrocalcinosis. Arthritis Research \& Therapy 19: 236. Link: https://bit.ly/3iKNpyL
14. Tong YU, Jun MA, Yan Jiang JL, Yunlong Gen YW, Wenjie SUN (2018) Assessing pain among Chinese elderly-chinese health and retirement longitudinal study. Iran J Public Health 47: 553-560. Link: https://bit.ly/3iKcObQ

15. Kearney GD, Allen DL, Balanay JAG, Barry P (2016) A descriptive study of body pain and work-related musculoskeletal disorders among Latino farmworkers working on sweet potato farms in eastern North Carolina. J Agromedicine 21 234-243. Link: https://bit.ly/2YdHXe9

16. Cho HY, Park YJ, Moon HH, Park SS, Kang GM, et al. (2015) The Effect of Swiss Ball Stabilisation Exercise on Deep and Superficial Cervical Muscle and Pain in Patients with Chronic Neck Pain. Indian Journal of Science and Technology 8 14. Link: https://bit.ly/39ZA1Tn

17. Da Costa BR, Vieira ER (2010) Risk factors for work-related musculoskeleta disorders: a systematic review of recent longitudinal studies. Am J Ind Med 53: 285-323. Link: https://bit.ly/2LZ2EYM

18. Abarqhouei NS, Hosseini Nasab H, Fakhrzad MB (2012) Design of the evaluation model for total ergonomics interventions with fuzzy approach. Sci J Pure Appl Sci 1: 119-129. Link: https://bit.ly/3phSktg

19. Morris LD, Daniels KJ, Ganguli B, Louw QA (2018) An update on the prevalence of low back pain in Africa: a systematic review and meta-analyses. BMC Musculoskeletal Disorders 19: 1-15. Link: https://bit.ly/39eNMyj

20. Wallace IJ, Worthington S, Felson DT, Jurmain RD, Wren KT, et al. (2017) Knee osteoarthritis has doubled in prevalence since the mid-20th century. Proceedings of the National Academy of Sciences 114: 9332-9336. Link: https://bit.ly/3sSuruE

21. Chen B, Li L, Donovan C, Gao Y, Ali G, et al. (2016) Prevalence and characteristics of chronic body pain in China: a national study. Springerplus 5 938. Link: https://bit.ly/39TJXO4

22. Kongtip P, Nankongnab N, Mahaboonpeeti R, Bootsikeaw S, Batsungnoen K, et al. (2018) Differences among Thai agricultural workers' health, working conditions, and pesticide use by farm type. Ann Work Expo Health 62: 167181. Link: https://bit.ly/39eMFyH

23. Shams-Hosseini NS, Vahdati T, Mohammadzadeh Z, Yeganeh A, Davoodi S (2017) Prevalence of musculoskeletal disorders among dentists in Iran: A systematic review. Mater Sociomed 29: 257-262. Link: https://bit.ly/3iJ47yl
Discover a bigger Impact and Visibility of your article publication with

Peertechz Publications

\section{Highlights}

* Signatory publisher of ORCID

* Signatory Publisher of DORA (San Francisco Declaration on Research Assessment)

* Articles archived in worlds' renowned service providers such as Portico, CNKI, AGRIS, TDNet, Base (Bielefeld University Library), CrossRef, Scilit, J-Gate etc.

* Journals indexed in ICMJE, SHERPA/ROMEO, Google Scholar etc.

* OAI-PMH (Open Archives Initiative Protocol for Metadata Harvesting)

* Dedicated Editorial Board for every journal

* Accurate and rapid peer-review process

* Increased citations of published articles through promotions

* Reduced timeline for article publication

Submit your articles and experience a new surge in publication services (https://www.peertechz.com/submission).

Peertechz journals wishes everlasting success in your every endeavours.

Copyright: ( 2021 Saeed O, et al. This is an open-access article distributed under the terms of the Creative Commons Attribution License, which permits unrestricted use distribution, and reproduction in any medium, provided the original author and source are credited. 